\title{
Strategic Management Accounting as a Source of Information for Value-Driven Project Management
}

\author{
Alina Kozarkiewicz and Monika Lada
}

\begin{abstract}
The main aim of this paper is to present the relevance of strategic management accounting for the contemporary projects and project-oriented organizations. Due to the fact that the modern project management is business-oriented and value-driven, it requires new sources of information. Therefore, the evolution from operational towards strategic project management accounting was demanded. The paper demonstrates the evolution of project management accounting - from cost calculation and budgeting towards measuring project value for key stakeholders. On the basis of literature review it is discussed how value measurement is addressed in the most popular methods of project strategic management accounting.
\end{abstract}

Index Terms-About project management, strategic management accounting, value creation, value measurement.

\section{INTRODUCTION}

In today's highly competitive environment the fast-paced creation of new and high quality products or services is crucial to business success. To meet the demands of dynamic changes, modern business requires operating at high performance, and new rules of processes and projects management have to be introduced. Nowadays, if a project has not delivered its expected value for stakeholders sponsor organization or its customers - it would not be seen as a success, although completed on time and cost [1], [2]. Project management has to be more business-oriented and value-driven, i.e. and must be viewed from the perspective of company's strategy, and must provide value to the essential stakeholders [3].

The measurement of the value created for various stakeholders: owners, customers, team members, business partners etc., generate the challenge for contemporary project management accounting. The measurement process has to comprise the multitude of stakeholders' expectations, should be extended towards measuring relations among projects in the company portfolio, as well as including potential value to be created in the future [4].

The main aim of this paper is to demonstrate how the complex and heterogeneous value generated by a project for its stakeholders can be translated into numbers.

This translation is enabled through the application of selected methods of strategic management accounting. The paper is based on the results of literature review, and the

Manuscript received April 25, 2013; revised June 27, 2013.

Alina Kozarkiewicz and Monika Lada are with the Faculty of Management, AGH University of Science and Technology, ul. Gramatyka 10, 30-067 Cracow, Poland (e-mail: akozarki@zarz.agh.edu.pl, mlada@zarz.agh.edu.pl). discussion is focused on the new approaches towards project value measurement within the most popular strategic management accounting methods.

\section{Strategic Management Accounting For PROJECTS AND PROJECT-ORIENTED ORGANIZATIONS}

Undeniably, monetary measurement, which is prevalent in accounting, is oriented to the correct assessment of value created for owners, and this is also reflected in the traditional management accounting approaches used by the managers of project organisations: project budgeting, project cost calculations, project profitability assessments are based on measuring selected financial measures that constitutes a key criterion for taking project-related decisions.

The new look at measuring the successes of the project, as mentioned above, has forced an evolution, and resulting in new methods of management accounting for projects. They are increasingly more often based on integrated measurement performed from the perspective of various stakeholders. Single-criterion analysis based on financial measures is swapped by multi-criteria assessments combining financial and non-financial measures. Moreover, the inclusion of stakeholders' expectations requires an extension of measurement beyond the activities of a project organisation, the introduction of new forms of describing existing relationships, as well as of clear rules for conflict resolution aiming at meeting the expectations of individual stakeholders.

The presented expansion of the scope of measurement in management accounting is associated with the development of methods grouped under the so-called strategic management accounting. At first it was associated with the need to measure factors creating the permanent competitive advantage, and over subsequent years it has been evolving together with the development of new concepts of strategic management [5]. In addition to the so-called competition accounting many new methods have appeared and have been named as customer accounting, environmental accounting or open-book accounting [6]. In general, strategic management accounting is defined as a group of accounting methods that provide financial and non-financial information to support the strategic management of organisations. Such information is used in the process of strategy definition, as well as in the stage of implementation and strategic control [7], [8].

The literature review demonstrates that the range of methods classified as strategic management accounting is very extended [9]. At present the most popular methods include strategy maps and the Balanced Scorecard, lifecycle costing, target costing, value chain or network profitability analysis and open-book accounting. All these methods share a 
single common feature: they counterbalance the attempt to meet the financial requirements of owners and they need to take into account the expectations and objectives of the key partners: direct and indirect customers or suppliers.

The mentioned above methods of strategic management accounting are used successfully in project activities [10], [11]. The approach they propose is so universal that you can use these methods to present both: repeatable activities and projects in a consistent way.

The scope of management accounting methods which are or can be used to support the strategic project management is constantly expanding. In the following chapter there are six, most popular methods chosen and presented. The methods are the examples of how the new approach towards success perception can be translated into the quantification process to be realized in the practise of project-oriented organisations.

\section{VAlue CREATion AND MEASUREMENT IN THE SELECTED Methods of Project MANAgEMENT ACCOUnting}

\section{A. The Balanced Scorecard and Strategy Maps}

Performance measurement systems seem to be these instruments of strategic management accounting in which the measurement of the value created and provided to many stakeholders was discussed at the earliest. The most popular instrument of performance measuring is the Balanced Scorecard. It is a modern system built on the basis of a set of measures constructed according to company's vision and strategy, and it combines different perspectives of company evaluation, ensuring balance between short and long term goals, financial and non-financial measures, rates describing past and future, and between objective and subjective measures [12]. With some simplification it can be concluded that the Balanced Scorecard is a list of measures connected with the realization of company's strategic targets expressed in four perspectives: financial, customer, internal business processes, and learning and grow. In each of these perspectives the strategic goals are decomposed into the detailed targets and monitored with the use of measures, which allows for determining if a strategy is realized according to the assumptions adopted.

In the first years of disseminating the idea of the BSC its authors concentrated on presenting its role in the process of strategy implementation. The usefulness of the BSC was indicated as the basic instrument ensuring better adjustment of operational activity to the strategy, and the role of the BSC in the process of establishing strategy was not so much emphasized. The letter problem was dealt with the next concept of strategy maps [13]. The strategy maps are diagrams showing the links between key assumptions of organisation's strategy. The key strategic factors are analogically grouped as in the case of the Balanced Scorecard.

In the case of the performance measurement for projects we can observe similar tendencies towards application of systems connecting different perspectives. The financial measures still play the primary role, as it is hard to ignore the significance of recording and measuring project costs, revenue, margin and determining the profitability of project activities. At present it is also necessary to use non-financial measures for project evaluation, which inform about relations with a customer, novelty of the products or services, as well as about the development of employees skills and knowledge. The project evaluation includes measures facilitating comparison with competition, the assessment of project influence on environment or creation of competitive position.

It seems to be obvious that the BSC and strategy maps are important methods of strategic project management accounting clearly focused on various stakeholders [14], [15]. The purpose of the financial perspective of the BSC is to measure the value creation for the owners. The introduction of the customer perspective provides this group of stakeholders with a significant role - this perspective aims at measuring a value delivered to customer, and a value which a customer delivers to the organisation. In the next perspectives the role of other stakeholders is taken into consideration, e.g. satisfaction and engagement of projects' teams appear as a crucial factor for further development, and cooperation with business partners and suppliers is a condition of high operational performance.

The BSC expands the measurement of value: it allows for the analysis of synergy and compromises in value creation, as well as for the analysis of cause and effect relations between individual components of a value provided for stakeholders. The BCS and strategy maps constitute instruments, which not only expand the measurement outside the organisation, but also enable to include the relations between creations of value for different stakeholders, as well as offer a measurement of a potential generated by an organisation. The learning and grow perspective gives the answer to the challenges relating to the necessity of measuring knowledge and relations crucial for the company's further development.

\section{B. Life Cycle Costing}

Life cycle costing (LCC) is one of the modern concepts of management accounting, mainly relating to products, but easily applicable in the case of projects, technologies, companies and whole sectors. The costs in life cycle costing are the overall costs of all activities undertaken, i.e. the analysis is not completed when the revenue is generated, but it also includes warranties, supply of spare parts, customer service, and disposal of packaging etc.

Obviously, the life cycle costing can be referred to projects-the life cycle of a project includes all activities: from identification of a need for implementing a project to the project completion in a form of disassembly or disposal [16]. In the case of the projects delivered to external customers the end of the life cycle of a project is the beginning of a life cycle of a product of the project, which is realized at the customer's facility. In the case of internal projects, the life cycle of a project's product relates to the project executor.

In general, the life cycle costing can be conducted in three perspectives:

- In the perspective of a project's product just as it is, without including the place of cost generation, by analysing and adding the costs incurred from the initial phases connected e.g. with acquiring raw material to the disassembly and disposal of all product remains and its packaging; 
- In the perspective of a project executor, i.e. including the costs incurred by the company realizing the project, starting from costs of concept creation phases, researches, preparing resources, through costs of usage and sales to the costs of in-warranty repairs and post-sales service;

- In the perspective of a customer-user, i.e. analysing costs of installation, exploitation, repairs and maintenance, liquidation and disposal of waste.

From the point of value creation and measurement, it is to be underlined that the life cycle costing of a project allows for the measurement of values generated for various stakeholders, including owners (sponsors) and customers, and it enables to search for a balance between the stakeholders' expectations, i.e. for a compromise in value creation.

The life cycle costing is an exemplary tool of strategic project management accounting which develops the scope of analysis and cost measurement outside the frames of organisation realizing the project: depending on the adopted perspective of making such costing it includes costs incurred by manufacturers of materials or subassemblies, or costs incurred by customers due to the purchase, utilization and disposal of project's product. The life cycle costing takes advantage of value co-creation as well: including the costs of external entities which are closer (e.g. suppliers of subassemblies) or further in the value chain (e.g. agents) makes possible to determine the level of their influence on the final value for a customer.

\section{Target Costing}

Target costing is a type of decision support calculus used in the process of product design, and its essence is the reduction of product's cost in such a way that it enables a company to fulfil the requirements of the owners, as well as the expectations of the customers. To support the process of product design, target costing offers information on the planned cost of its production and supply to the customers.

According to the definition, target costing is a method focused on determination of costs, which when incurred ensures the manufacturing of the planned product having adequate quality and functionality and which sale for the assumed price shall ensure the desired level of profitability [17]. In general, the proposed procedure of such costing assumes that the starting point of product design is the determination of a target price which the consumers are willing to pay for the product. The second starting point of target costs analysis is the determination of a profit margin which the organisation would like to secure from the sales of a product. The target cost of a product is calculated as follows: target selling price minus target margin equals to target cost of a product. This formula providing the target cost of a product constitutes only an introduction to numerous simulations aiming at reliable determination of anticipated costs of a product and its value for customers with different, considered design preferences.

Target costing is an important method of strategic project management accounting. Due to the role which the target costing plays in the shaping of a value for a customer at the stage of product design, and owing to the transparent procedure of searching for a compromise between the value of a product and its cost, this solution can be applied effectively in the case of the products acquired as a result of certain projects. In the project management the basic project characteristics are described as a triangle: scope, time and quality, which - in broader sense - can be described as the product's value for a consumer. The strict connection between the scope, time and quality of a project and its cost constitutes the basis for project analysis in the target costing.

It can be underlined that the target costing is an important method of strategic management accounting of projects which assumes simultaneous application of analyses relating to different financial and non-financial aspects of project's products and of expectations of different stakeholders: owners, customers, and often suppliers of materials or subassemblies. This method develops the measurement of a value outside the project and outside the organisation. The idea of searching for a compromise in creating a value results from the essence of target costing: the calculated, target level of project's product price is determined as a result of expectations of customers and owners, and is not an outcome of internal designers' assumptions.

\section{Value Chain Costing}

According to basic understanding, the value chain reflects the determined economic path and it can be analysed in various perspectives: individual sector as a link in the value chain of economy, each company in an individual sector as a link of a chain made of suppliers, the company itself and its recipients, internal activities within a company as links that create value for a customer.

There are two main types of analysis in the strategic management accounting: the analysis of external and internal value chain. The external value chain is perceived as a group of companies engaged in all stages of a product life cycle from acquiring the raw material till recycling, and an individual company constitutes a link of such chain and is connected with suppliers, suppliers of the suppliers, recipients, recipients of the recipients etc. The internal value chain comprises the set of primary and support activities realized within a company, and as the result of those activities the value for a customer is created [18].

Contemporary strategic management accounting offers the analyses made within the frames of value chain including various alternatives: the basis of the analysis can be the external or internal value chain, and the specific subject can be the analysis of costs, revenue or profitability.

The value chain analysis can be applied successfully in the project activity. In the strategic management accounting of projects we can use both the analysis of costs and profitability, and the subject of analysis can be the set of linked entities (suppliers, recipients of project's products), as well as the set of primary and support activities of a project.

The analysis of profitability conducted within the frames of external value chain is an instrument for value decomposition and constitutes another example of the extension of application of traditional management accounting from one entity to many cooperating organisations. The extension of measurement is also strictly connected with the concept of value co-creation by related companies. The decomposition of revenue, acquired from target customers, into individual organisations enables to evaluate in detail how the value is 
created.

The analysis of internal value chain is also an instrument for value decomposition, in this case a subject to decomposition are individual activities connected with realization of a project. The analysis of costs and values includes both the value for the owners, as well as the value for customers, but the starting point is the value created for customers, and there are places (activities) indicated in which the value is generated (or is subject to destruction). The analysis of costs and profitability within the frames of value chain allows one to understand and improve internal process of creating project value.

\section{E. Open-Book Accounting}

The label 'open-book accounting' does not reflect any specific instrument or procedure of management accounting, but it rather describes a specific approach towards usage of accounting data for the purposes of management of relations between independent but related (in terms of cooperation) organisations [19].

According to the definition, the open-book accounting is a strategy that leads towards co-operation between firms situated in a supply chain, and this information is used to influence the flow of products and services between the firms in question [20]. It should not be assumed that the partners are provided with all accounting data - the scope of submitted information should be clearly defined and adequate to the planned purposes of cooperation. Moreover, the scope of exchanged information is often broader than the accounting data and relates also to such issues as e.g. production capacity, technologies used or opinions on customer expectations.

The open-book accounting can be applied in the project activity - the unique and individual character of a projects' product makes it to be prepared and realized with reference to specific needs of a customer, and this requires strict cooperation with customer at the stage of developing project's concept. The assumption is as follows: the recipient (project's sponsor) should cover all costs of a project through product's price, thus the determination of project value for a customer should be connected with cost analysis.

Unquestionably, the open-book accounting is based on the concept of value co-creation and synergy of value. The demand for management information exchange and joint activities in order to improve the efficiency of the whole network results in the assumption that the value for a target customer is not only shaped by an individual organisation. The joint effort leading to the acquisition of the determined effects requires adequate management tools at the level of business networks. Regardless of whether management at this level is a centralized system with a network integrator or a dispersed system of individual, direct partners, it is necessary to acquire a reliable accounting data collected from many business entities.

Summing up, the instruments of project management accounting described above are the examples illustrating the new approach toward value measurement. Although these methods do not exhaust the whole potential for strategic management accounting, they clearly present the common rule of their construction - the translation of stakeholders' values into accounting numbers.

\section{CONCLUDING REMARKS}

The shift in project management-from narrow and technical focus to broader and more value-oriented approach, has given rise to the search for new sources of managerial information. As it was demonstrated, contemporary management accounting offers an extended range of methods that can be used for the purpose of strategic project management. The main characteristic of these methods is the focus on the measurement of the complex and multidimensional value that projects deliver to their stakeholders. Practical application of these methods extends the scope of information available to managers from traditional data on project cost to numbers depicting project value.

The process of adjusting and implementing these methods as well as integrating them into a consistent information system is complicated; however it offers to managers the advantage of looking at a project from stakeholders' perspective.

\section{REFERENCES}

[1] H. Kerzner and F. Saladis, Value-Driven Project Management, John Wiley \& Sons, 2009.

[2] A. J. Shenhar, D. Dvir, O. Levy, and A. C. Maltz, "Project success: a multidimensional strategic concept," Long Range Planning, vol. 34, pp. 699-725, 2001.

[3] E. Frigenti and D. Comninos, The Practice of Project Management - A Guide to the Business-Focused Approach, Kogan Page, 2002.

[4] A. Kozarkiewicz, "Project portfolio management: implementing and monitoring organization strategy through projects," Zarzadzanie Portfelami Projektów Wdrażanie I Monitorowanie Strategii Organizacji Za Pomoca Projektów, 2012.

[5] R. Dixon, "Accounting for strategic management: a practical application," Long Range Planning, vol. 31, no. 2, pp. 272-279, 1998.

[6] R. Roslender and S. J. Hart, "In search of strategic management accounting: theoretical and field study perspectives", Management Accounting Research, vol. 14, pp. 255-279, 2003.

[7] J. K. Shank and V. Govindarajan, "Strategic cost management," The New Tool for Competitive Advantage, The Free Press, New York, 1993.

[8] K. Ward, Strategic Management Accounting, Routledge, 2012.

[9] Z. Hoque, Strategic Management Accounting, Pearson Prentice Hall, 2006.

[10] M. M. Łada and A. Kozarkiewicz, "Management accounting and controlling of projects," Rachunkowość Zarzqdcza I Controlling Projektów, C.H. Beck, Warsaw, 2007 (in Polish).

[11] M. M. Łada and A. Kozarkiewicz, "Managing project value," "The tools of management accounting and controlling," Zarzqdzanie Wartościq Projektów, Instrumenty Rachunkowości Zarzq̨dczej I Controllingu, C.H. Beck, Warsaw, 2010 (in Polish).

[12] R. S. Kaplan and D. P. Norton, The Balanced Scorecard. Translating Strategy into Action, Harvard Business School Press, Boston, 1996.

[13] R. S. Kaplan and D. P. Norton, Strategy Maps: Converting Intangible Assets into Tangible Outcomes, Harvard Business School Press, Boston, 2004.

[14] K. Milis and R. R. Mercken, "The use of the balanced scorecard for the evaluation of information and communication technology projects," International Journal of Project Management, vol. 22, pp. 87-97, 2004.

[15] J. Norrie and. D. H. T. Walter, "A balanced scorecard approach to project management leadership," Project Management Journal, vol. 35, no. 4, pp. 47-56, 2004.

[16] D. G. Woodward, "Life cycle costing-theory, information acquisition and application", International Journal of Project Management, vol. 15, pp. 335-344, 1997.

[17] R. Slagmulder and Cooper, Target costing and value engineering, Institute of Management Accountants, Montvale, 1997.

[18] M. E. Porter, Competitive advantage. Creating and sustaining superior performance, The Free Press, New York, 1985. 
[19] M. Łada, "Open-book accounting-the outlines of the concept," "Rachunkowość otwartych ksiag-zarys koncepcji," Zeszyty Teoretyczne Rachunkowości, vol. 49, pp. 131-143, 2009.

[20] J. Mouritsen, A. Hansen, and C. Ø. Hansen, "Inter-organizational controls and organizational competences: Episodes around target cost management/functional analysis and open book accounting," Management Accounting Research, vol. 12, pp. 221-244, 2001.

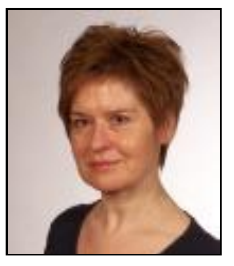

Alina Kozarkiewicz awarded her master in management from the AGH-University of Science and Technology, the Faculty of Management in Cracow, Poland in the year 1987. Next, in the year 1997 she awarded doctoral degree in management from the same University. She works for the AGH-University of Science and Technology in Cracow, Poland, since her graduation, holding the positions of teaching assistant and next assistant professor. She co-operated with numerous Polish universities, e.g. Warsaw School of Economics, Medical University in Warsaw, School of Management and Banking in Cracow. She visited and co-operated with many European universities, e.g. Umea University in Sweden, Dundee University in the UK or Arcada University in Helsinki in Finland. Her main interests include project management, innovation management and strategic management. She is an author or co-author of 5 books on project management and project management accounting (all in Polish) and of over hundred scientific papers. She presented her work at numerous conferences in Poland and abroad.

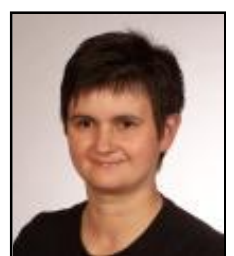

Monika Lada awarded her master in management from the AGH-University of Science and Technology, the Faculty of Management in Cracow, Poland (1994) In the year 1999 she awarded doctoral degree in economics from the University of Economics in Katowice, and next in the year 2012 post-doctoral degree (habilitation) from the same University. She works for the AGH-University of Science and Technology in Cracow, Poland. She had the positions of teaching assistant and next assistant professor. At present she is Deputy Dean of the Faculty of Management AGH-UST in Cracow. She co-operated with numerous Polish and foreign universities, e.g. Warsaw School of Economics, Umea University in Sweden, and Dundee University in the UK. Her interests are concentrated on management accounting. Within this area such specific issues as project management accounting and customer accounting are dominating. She is an author and co-author of 6 books on management accounting and project management accounting, as well as of over hundred scientific publications. 